\title{
HOMOGENEOUS ENZYME-LINKED ASSAYS MEDIATED BY ENZYME ANTIBODIES; A NEW APPROACH TO ELECTRODE-BASED IMMUNOASSAYS
}

\author{
SUSAN B. BRONTMAN and M. E. MEYERHOFF* \\ Department of Chemistry, The University of Michigan, Ann Arbor, MI 48109 (U.S.A.)
}

(Received 30th March 1984)

Summary. A new homogeneous enzyme-immunoassay system is described. The assay employs an ammonia-liberating enzyme covalently coupled to protein antigens along with two antibodies. An anti-enzyme antibody inhibits the enzyme. However, an antibody selective for the antigen reverses the inhibition process. When samples containing free antigen are present in the assay mixture, there is competition for anti-antigen antibody sites and protection against the anti-enzyme antibodies is diminished. The extent of the enzymatic reaction is monitored with an ammonium ion-selective electrode. Preliminary data demonstrating the feasibility of this approach for human serum albumin are presented.

The development of novel non-isotopic competitive binding immunoassays for the detection of antigens in physiological fluids has become an important area of bioanalytical research. Such assays offer attractive alternatives to the more traditional radioimmunoassay methods. Enzymes have emerged recently as effective labels for immunoassay methods [1-3]. This communication describes a new homogeneous enzyme immunoassay arrangement.

The proposed assay (see Fig. 1) utilizes the enzyme, adenosine deaminase (ADA), which catalyzes the hydrolysis of adenosine to inosine and ammonia [4]. The enzyme is covalently coupled to an analyte protein. Also, two antibody reagents are required, one selective for the protein to be measured and a second one directed toward the active site of the enzyme. When antibodies selective for the antigen are first added to the enzyme conjugate, these antibodies partially protect the enzyme from inhibition when the enzyme antibodies are added, thereby increasing the catalytic activity observed. When samples containing free antigen are present in the assay mixture, a competition for the anti-antigen antibody sites occurs and protection against the anti-enzyme antibodies is diminished. The extent of the enzymatic reaction can be monitored with an ammonium ion-selective electrode.

The feasibility of this new assay approach is demonstrated by developing an assay for the model protein, human serum albumin (HSA). The factors which limit sensitivity and speed of the assay are discussed as are prospects for improving the overall quantitative characteristics of the technique. 


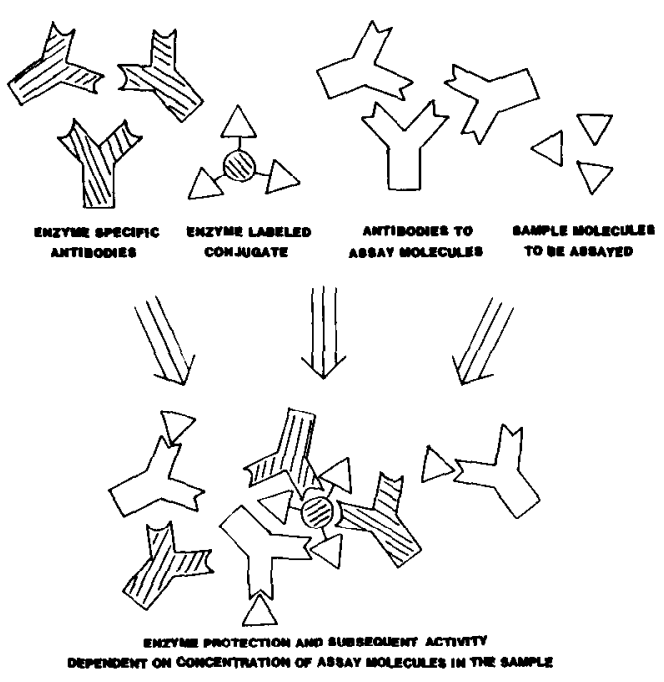

Fig. 1. Representation of reagents used and processes that take place in the proposed assay.

\section{Experimental}

Apparatus. Potentiometric measurements were made with a tubular flowthrough ammonium ion-selective electrode based on nonactin [5] in an autoatic continuous flow arrangement. Fractions obtained from size-exclusion chromatography of ADA-HSA conjugates were collected with an ISCO model 1850 fraction collector with continuous photometric monitoring of the effluent. All incubations for the enzyme immunoassays were performed in 3-ml borosilicate glass tubes.

Reagents. Reagents obtained from Sigma Chemical Company were adenosine deaminase (ADA) type III from calf intestinal mucosa, human serum albumin (HSA) fraction $\mathrm{V}$, adenosine, tris(hydroxymethyl)aminomethane (Tris), Sephadex G-100, and glutaraldehyde (grade I, aqueous 25\% solution). All other chemicals were reagent grade. Standards and working buffer solutions were prepared with distilled-deionized water.

A $0.01 \mathrm{M}$ Tris/sulfuric acid buffer, $\mathrm{pH} 7.5$, containing $0.5 \mathrm{mM}$ ethylenediaminetetraacetic acid [4] was used as the working buffer. A $0.1 \mathrm{M}$ phosphate buffer, pH 7.0, was used when preparing ADA-HSA conjugates via the glutaraldehyde cross-linking reaction.

Antisera were prepared and provided by the Unit for Laboratory Animal Medicine at the University of Michigan. For working antibody reagents, each antiserum lot was subjected to an ammonium sulfate fractionation to isolate the $\gamma$-globulin components of the serum [6].

Preparation and purification of $A D A-H S A$ conjugates. The ADA was cross-linked to HSA by a glutaraldehyde reaction [7]. The conjugate was prepared by mixing $2 \mathrm{mg}$ of HSA and $0.20 \mathrm{mg}$ of ADA in $2 \mathrm{ml}$ of phosphate buffer. The protein solution was dialyzed extensively against three 1-1 
volumes of the phosphate buffer. The solutions were then placed in a glass test tube and gently stirred as $150 \mu 1$ of $1 \%$ glutaraldehyde was added in $50-\mu l$ increments over the first $2 \mathrm{~h}$ of the reaction. After $4 \mathrm{~h}$, the reaction mixture was centrifuged at $2200 \mathrm{~g}$ for $15 \mathrm{~min}$ at $4^{\circ} \mathrm{C}$. The supernatant solutions were then dialyzed against the Tris working buffer. These conjugates were then partly purified as follows: a fraction of the conjugate was passed through a Sephadex G-100 size-exclusion column and the effluent was continuously monitored at $280 \mathrm{~nm}$. As protein began to elute, $0.5-\mathrm{ml}$ fractions were collected.

Determination of relative $A D A$ activity. Aliquots $(10 \mu \mathrm{l})$ of ADA or ADA-HSA conjugates (from the fractions) were added to $1.49 \mathrm{ml}$ of working buffer in test tubes and $50 \mu \mathrm{l}$ of $5 \mathrm{mM}$ adenosine solution was added to initiate the reaction. After 15 or $60 \mathrm{~min}$ (depending on the absolute activity of the ADA in the sample), $50 \mu \mathrm{l}$ of $0.02 \mathrm{M}$ silver nitrate was added to the tube to stop the enzymatic reaction. Ammonium ions produced were quantified and corrected for amounts produced in a similar blank reaction.

Only fractions from the size-exclusion column with highest protection characteristics were used in subsequent assays by the proposed method.

Procedure for calibration curves for HSA. Assays were run in triplicate. First, $1.10 \mathrm{ml}$ of working buffer was added to each tube followed by $100 \mu \mathrm{l}$ of an HSA standard solution and $100 \mu \mathrm{l}$ of diluted HSA antibody. After $20 \mathrm{~min}, 100 \mu \mathrm{l}$ of diluted $\mathrm{HSA}-\mathrm{ADA}$ conjugate was added and the mixture was incubated at room temperature for another $20 \mathrm{~min}$. Subsequently, $100 \mu \mathrm{l}$ of the diluted ADA antibody reagent was added and after another $20 \mathrm{~min}$ of incubation, $50 \mu \mathrm{l}$ of adenosine solution was added and silver nitrate was added after $1 \mathrm{~h}$. The ammonium content was determined as described above.

Calibration curves were constructed by arbitrarily assigning the amount of ammonium ions produced from the "protected" enzyme conjugate as $100 \%$ activity and that level produced from the inhibited conjugate as $0 \%$.

\section{Results and discussion}

The pure ADA used here was inhibited up to a maximum of $72 \%$ even in the presence of excess of the anti-ADA antibody preparation. Nearly maximum inhibition $(70 \%)$ could be achieved using a 1:100 dilution of this antibody. Fractions of the ADA-HSA conjugate most effective for the proposed type of assay were also generally inhibited up to $70 \%$ with the same 1:100 dilution of the antibody preparation. Thus, the covalent attachment of HSA to the enzyme apparently does not preclude inhibition of the enzyme by anti-ADA antibodies. None of the ADA-HSA fractions obtained from the size-exclusion procedure exhibited full activity in the presence of anti-HSA antibodies. The ADA-HSA conjugates prepared to date are activated (protected) up to $32 \%$ (e.g., from $70 \%$ to $38 \%$ inhibition) in the presence of anti-HSA antibodies. Despite this rather narrow range of enzyme modulation, the conjugates prepared were useful to demonstrate the principle of the new method. 


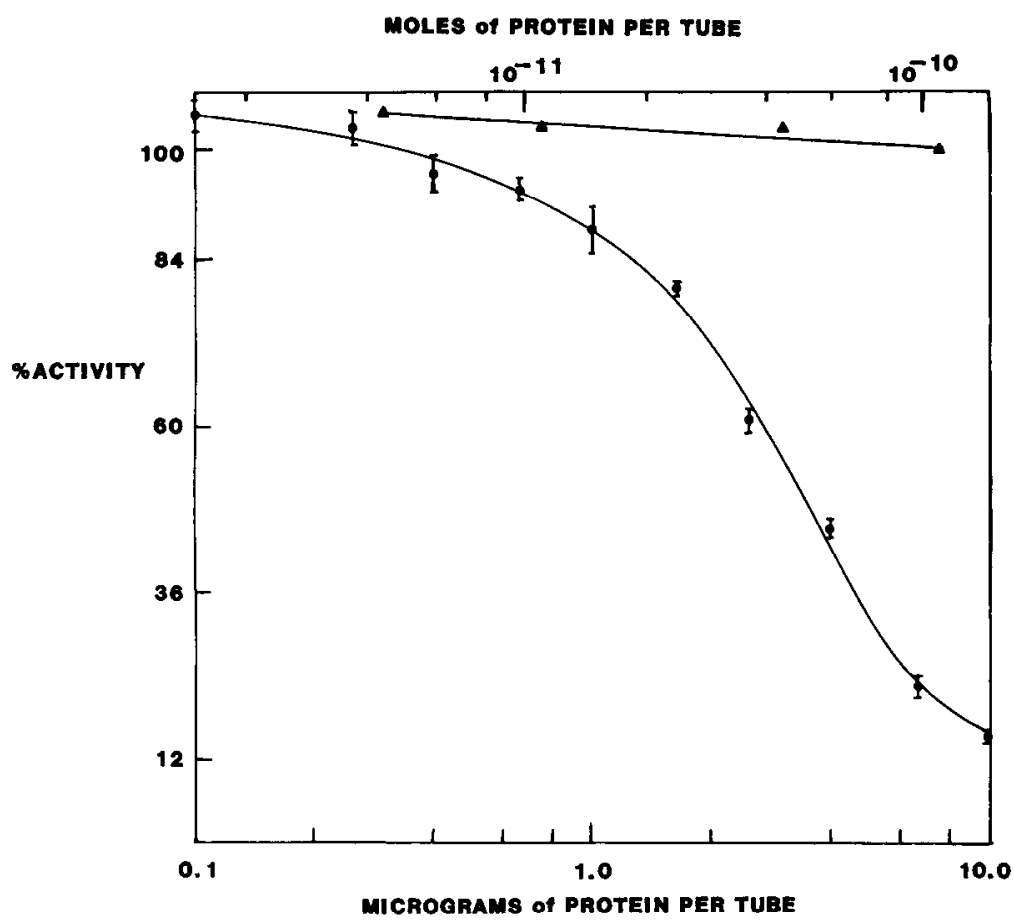

Fig. 2. Calibration curve obtained for detection of free HSA ( $\bullet$ ); data points shown are average of triplicate measurements with standard deviation. Also shown is the response of the system to varying free myoglobin levels ( $\Delta)$.

Figure 2 shows a typical calibration curve obtained when free HSA concentrations were varied with an ADA-HSA conjugate fraction that can be protected up to $32 \%$. It can be seen that the reproducibility is quite good for triplicate samples; slightly less than $1 \mu \mathrm{g}$ of HSA protein could be detected, which is similar to the detection limit of another homogeneous enzyme immunoassay [8]. Figure 2 also shows that increasing concentrations of myoglobin did not significantly affect the ability of anti-HSA antibodies to protect the ADA-HSA conjugate.

The use of a new, more controllable cross-linking reagent, $N$-succinimidyl 3-(2-pyridyldithio)propionate [9], may permit detection limits and assay times to be reduced by producing an ADA-HSA conjugate that is more fully protected; work in this direction is currently under way. In addition, sizeexclusion chromatography with gels possessing larger fractionation ranges should also aid in obtaining a more suitable conjugate.

Data presented here demonstrate the feasibility of the proposed approach. It is expected to be applicable with other enzymes, other antigens, and other types of detectors. Modifications of the experimental system would be required for clinical samples. 
The authors gratefully acknowledge the National Science Foundation for supporting this work (Grant CHE-8118817).

\section{REFERENCES}

1 G. B. Wisdom, Clin. Chem., 22 (1976) 1243.

2 S. L. Sharpe, W. M. Cooreman, W. J. Blumme and G. M. Leekeman, Clin. Chem., 22 (1976) 733.

3 A. H. W. M. Schuurs and B. K. Van Weeman, Clin. Chim. Acta, 81 (1977) 1.

4 Biochemica Information I, Boehringer-Mannheim, 1975, p. 24.

5 Y. M. Fraticelli and M. E. Meyerhoff, Anal. Chem., 53 (1981) 992.

6 D. H. Campbell, J. S. Garvey, N. E. Cremer and D. H. Sassdorf, Immunology, W. A. Benjamin, New York, 1964, pp. 118-120.

$7 \mathrm{~S}$. Avrameas, Immunochem., 6 (1969) 43.

8 I. Gibbons, C. Skold, G. L. Rowley and E. F. Ullman, Anal. Biochem., 102 (1980) 167.

9 D. Pain and A. Surolia, J. Immunol. Methods, 40 (1981) 219. 